\title{
The Effect of International Hotel Employee Loyalty on Customer Behavioral Intention in Taiwan
}

\author{
Yen-Cheng Chen ${ }^{1}$, Pei-Ling Tsui ${ }^{2.3^{*}}$, Ching-Sung Lee ${ }^{4}$ \\ ${ }^{1}$ Department of Applied Science of Living, Chinese Cultural University, Taiwan \\ ${ }^{2}$ Department of Hospitality Management, National Taitung College, Taiwan \\ ${ }^{3}$ Graduate Institute of Technological and Vocational Education, National Taipei University of \\ Technology, Taiwan \\ ${ }^{4}$ Department of Restaurant, Hotel and Institutional Management, Fu Jen Catholic University, Taipei, \\ Taiwan \\ *Corresponding author: J2217013@ms48.hinet.net
}

\begin{abstract}
When it comes to customer satisfaction, employee loyalty seems to be an obscure contributor. However, there is evidence suggesting that employee satisfaction positively affect customer satisfaction and loyalty. We can see in literature that researcher's debate on the effects of employee loyalty. Most literature suggest that employee loyalty is beneficial that it reduces turnover intention and burnout, and increase organizational commitment. Employee loyalty is also proved connected to customer satisfaction and loyalty. Service profit chain theory explains that how employee loyalty within a high-contact service context facilitates higher service quality and performance, and makes good impression on customers exhibiting by high level of customer satisfaction and loyalty. However, will employee loyalty also affect customers' behavioral intention is rarely discussed. This study attempts to clarify this connection by conducting survey. Questionnaire is distributed to both employees and customers of high-class restaurants. Data is collected and analyzed with SPSS 20.0 package software. The results illustrate a positive relation between employee loyalty and customer behavioral intention. Restaurant managers can refer to this result and take measures to improve the level of employee loyalty to earn more profit.
\end{abstract}

Keywords: international hotel, employee loyalty, behavioral intention

\section{INTRODUCTION}

In the recent development of hospitality industry, businesses such as international hotels have suffered from a high turnover rate of service personnel. International hotels in Taiwan increasingly use part-time workers and internship students as main sources of first line service providers. Practitioners argue that this strategy is going to lower labor costs and to improve overall profit, while scholars have warned that this approach is likely to reduce competitiveness if experienced workers were gratuitously lost (Li, Kim, \& Zhao, 2017; Brown., Bosselman, \& Thomas, 2016; Hinkin \& Tracey, 2000). Employee loyalty is a recognized predictor of turnover intention and behaviour. As suggested by Davidson, Timo, and Wang (2010), turn over problem is a great challenge to human resource strategy and organization performance, and the stake of turnover is high. The approach of practitioners greatly contradicted to theory. Therefore, the question we are trying to clarify in this study is whether hotel managers should hire more part-time employees to lower labour costs and regard high turnover rates as the inevitable, or make some changes to retain experienced employees, as this would help improving customer satisfaction and loyalty, and the profit in the future. If managers can have a clarified view on this issue, they would make better decision strategically and by this improving profitability of hotels.

Employee satisfaction is defined as "the pleasurable emotional state resulting from the appraisal of one's job as achieving or facilitating the achievement of one's job values" (Karatepe, Kaviti, \& Kaviti,2016; Locke, 1969). According to Oxford Dictionary Online, 'loyal' is defined as "giving or showing firm and constant support or allegiance to a person or institution", and 'loyalty' is defined as "a strong feeling of support or allegiance". Customer satisfaction is an evaluation that concludes the experience was at least as good as it was supposed to be(Hunt, 1977; Tongchaiprasit, \& Ariya bud dhiphongs, 2016) and determined by expectations and other pre-experience standards, product-service 
performance, and factors affecting the customer's actual perception of the service(Barsky \& Labagh, 1992).Employee loyalty can display in forms of employees' extra effort in executing their tasks, respecting company value and supervisors' order (Costen \& Salazar, 2011; Matzler \& Renzl, 2006). Customer loyalty is illustrated when customers show repeat patronage, spread good word-of-mouth of companies (Cronin Jr, Brady, \& Hult, 2000; Dick \& Basu, 1994). The theory of service profit chain which links these pieces together(McGinley, Hanks, \& Line, 2017; Heskett, Sasser, \& Schlesinger, 1997) clearly elaborates how companies turn internal service quality into employee satisfaction, and then into customer satisfaction, loyalty, and financial performance. Researchers have debated over the service profit chain first proposed by Heskett et al. (1997) of whether viewing from different perspectives or the missing pieces of the theory. For instance, Homburg, Wieseke, and Hoyer (2009)proposed a social-identity perspective of service profit chain and compared it to conventional service profit chain path from employee satisfaction to customer satisfaction and loyalty. The effect of new service profit chain path was clearly more significant than the conventional one. Some empirical examinations of applying service profit chain to various businesses and industries are available. Gelade and Young (2005); Loveman (1998) both verified the links of service profit chain in retail banking, and found the result generally support the relationships of employee satisfaction and loyalty to customer satisfaction and loyalty to finally financial performance of a company. Another positive study of Brazil banks made by Kamakura, Mittal, de Rosa, and Mazzon (2002) proved that branch managers will obtain higher level of performance if they can manage to maintain high level of employee satisfaction. Silvestro and Cross (2000) investigated the effect of service profit chain in retailing grocery company of UK. They found a 'mirror effect' between customer and employee satisfaction and proved that service profit chain indeed works in retailing businesses. Kassinis and Soteriou (2003) explored the positive effect of environmental management in European hospitality industry on the service profit chain and how it influenced company performance. These studies confirmed the significance of service profit chain, but there is still lack of empirical evidences from hospitality industry in Asia region. This study will be able to fill this gap by investigating the effect of service profit chain within international hotels in Taiwan.

Therefore, for first line service providers in international hotels, we propose the following hypotheses assuming the work content of part-time and formal employees are identical:

H1: Satisfaction of part-time employees differs from formal employees.

H2: Loyalty of part-time employees differs from formal employees.

H3: Employee satisfaction has direct effect on employee loyalty.

H4: Employee loyalty has direct effect on customer satisfaction.

H5: Customer satisfaction has direct effect on customer loyalty.

\section{METHOD}

To reduce the possibility of common method bias, data were collected respectively in two steps from employees and customers of the international hotels. Prior to the survey, consent was acquired from the managers of three selected international hotels in Taipei, and aquestionnairewasdistributedto30 randomly selected first-line service employees at each hotel, totally 90 employees were surveyed. These employees include both part-time and formal employees. Researchers guaranteed to the participants that the questionnaire will be completely anonymous and not be used in any circumstances other than scientific purposes. The employees answered the questionnaire to express their satisfaction and loyalty regarding the target hotel. Researchers then distribute another questionnaire to customers passing through the hotel lobby to measure customer satisfaction and loyalty about the target hotel.

Questionnaires assessing employee satisfaction and loyalty were hand distributed by the researchers to 90 first-line service employee sat three international hotels located in Taipei. Upon completion, researchers checked the questionnaire for missing answers and apparent biased answering patterns. Participants were asked to clarify their answers immediately at the scene, therefore all employee questionnaires returned were eligible to statistical processing. To measure customers' satisfaction toward the most recent service they received from the target hotel and how would they describe their loyalty to the target hotel, a questionnaire was administered to customers passing through the hotel lobby. After eliminating defective questionnaires, the final total we can use for further statistical processingis 183 customer responses (of $90.7 \%$ was successfully recovered). A total of 90 employees and 183 customers responses comprise the data and were used to test the hypotheses. 
We arranged the measures in this study into five categories: employee satisfaction, employee loyalty, customer satisfaction, customer loyalty, and demographic characteristics. The survey instrument used to measure employee satisfaction, employee loyalty, customer satisfaction, and customer loyalty included a 5-point scale: "How much do you agree or disagree with these statements?" (1:strongly disagree to 5: strongly agree).We measured employee satisfaction by deploying abridged job descriptive index (JDI), which was initially proposed by Smith, Kendall, and Hulin (1969), and then extensively implemented, examined, revised and modified in literature (Ironson, Smith, Brannick, Gibson, \& Paul, 1989; Kinicki, McKee-Ryan, Schriesheim, \& Carson, 2002; Roznowski, 1989; Stanton, Bachiochi, Robie, Perez, \& Smith, 2002).JDI measures job satisfaction using 5 facets and 30 items: work on present job, present pay, promotion opportunities, supervision, and coworkers.We measured employee loyalty with four items adapted from McCarthy (1997), namely intention to stay, willingness to perform extra work, sense of belonging, and willingness to take up more responsibility. Customer satisfaction was measured by four items based onBitner (1990); Fornell, Johnson, Anderson, Cha, and Bryant (1996). Items in the scale included "I really enjoyed myself at the hotel", and "Overall, I am satisfied with my experience at this hotel." In addition, customer loyalty was measured by four items developed by Cronin Jr et al. (2000); Zeithaml, Berry, and Parasuraman (1996). Items in the scale included "I will keep an on going relationship with this hotel", and "I will put out good word-of-mouth of this hotel." Part four of the questionnaire contained questions eliciting demographic information from the customers (e.g., age, gender, and education level) and employees' information (e.g., age, gender, education level, job tenure, and job status).

Descriptive statistics were performed to profile employees' and customers' demographic characteristics. To test our hypotheses, we applied t-test to examine if there are significant differences of employee satisfaction and employee loyalty between part-time and formal employees ( $\mathrm{H} 1$ and $\mathrm{H} 2)$. Finally, we implemented regression analysis to find causal effects between each variable $(\mathrm{H} 3, \mathrm{H} 4$ and H5).

\section{RESULT}

The demographic characteristics are presented in Table 1 . The employees $(N=90)$ are mostly of age 20-29 years and under 20 years. Employees under age 20 are all intern students from cooperated colleges or vocational schools, in which the majority of employees (62.22\%) completed college/vocational school programs. The remaining employees have bachelor degrees in university, and only $3.33 \%$ of employees have master degrees. Male employees are the majority $(60.00 \%)$ in our investigation, and most employees have tenure 1-3 years and part-time contracts. For customers demographic characteristics, most customers have age 30-39 (44.81\%) and older than 40 (34.97) and possess bachelor degrees (59.56\%). More than half of the customers are female (58.47\%).

Table1. Demographic Characteristics

\begin{tabular}{|l|l|l|l|l|}
\hline Characteristics & \multicolumn{2}{|l|}{ Employee $(N=90)$} & \multicolumn{2}{l|}{ Customer $(N=183)$} \\
\hline & $N$ & Percentage & $N$ & Percentage \\
\hline Age & & & & \\
\hline Under 20 & 31 & $34.44 \%$ & 37 & $20.22 \%$ \\
\hline $20-29$ & 45 & $50.00 \%$ & 82 & $44.81 \%$ \\
\hline $30-39$ & 14 & $15.56 \%$ & 64 & $34.97 \%$ \\
\hline Older than 40 & 0 & $0.00 \%$ & & \\
\hline Education & & & 27 & $14.75 \%$ \\
\hline College/Vocational school & 56 & $62.22 \%$ & 109 & $59.56 \%$ \\
\hline Bachelor degree & 31 & $34.44 \%$ & 47 & $25.68 \%$ \\
\hline Master degree & 3 & $3.33 \%$ & & \\
\hline Gender & & & 76 & $41.53 \%$ \\
\hline Male & 54 & $60.00 \%$ & 107 & $58.47 \%$ \\
\hline Female & 36 & $40.00 \%$ & & \\
\hline Tenure & & & & \\
\hline $1-3$ years & 61 & $67.78 \%$ & & \\
\hline 4-6 years & 20 & $22.22 \%$ & & \\
\hline More than 6 years & 9 & $10.00 \%$ & & \\
\hline Job status & & & & \\
\hline Part-time & 57 & $63.33 \%$ & & \\
\hline Formal & 33 & $36.67 \%$ & & \\
\hline
\end{tabular}




\section{Yen-Cheng Chen et al.}

The results of t-test between formal and part-time employees focusing on employee satisfaction and employee loyalty are illustrated in Table 2. For employee satisfaction, formal employees have an average score of 3.57, and part-time employees 3.01. The t-value is 2.51 (significant level $p<0.05$ ). This supports our hypothesis 1 that formal and part-time employees have different levels of employee satisfaction. As for employee loyalty, the situation is similar with employee satisfaction. Formal employees have an average score 3.43 in employee loyalty, while part-time employees have only 2.91 . The $\mathrm{t}$-value is 2.94 (significant level $p<0.01$ ). Therefore, hypothesis 2 is supported.

Table2. T-Test for Employee Satisfaction and Loyalty

\begin{tabular}{|l|c|l|}
\hline & Avg.(Std.) & \multicolumn{1}{|c|}{$t$} \\
\hline Employee satisfaction & & \\
\hline Formal employee & $3.57(0.88)$ & $2.51^{*}$ \\
\hline Part-time employee & $3.01(1.07)$ & \\
\hline Employee loyalty & & \\
\hline Formal employee & $3.43(0.95)$ & $2.94^{* *}$ \\
\hline Part-time employee & $2.91(1.16)$ & \\
\hline
\end{tabular}

${ }^{*} p<0.05,{ }^{* *} p<0.01$

To confirm the causal relationships between major variables, we built three regression models each with dependent variables employee loyalty (model 1), customer satisfaction (model 2), and customer loyalty (model 3). Table 3 presents the standard beta coefficients of the independent variables and adjusted $R^{2}$ of the model. Model 1 suggests employee satisfaction positively affects employee loyalty $(b=0.35, p<0.01)$, therefore, hypothesis 3 is supported. Model 2 shows employee satisfaction $(b=0.19$, $p<0.05)$ and employee loyalty $(b=0.28, p<0.05)$ are both statistically significant predictors of customer satisfaction, and so hypothesis 4 is supported. We can see that in Model 3, customer satisfaction significantly affect customer loyalty $(b=0.41, p<0.01)$, but not employee satisfaction and employee loyalty, thus supporting hypothesis 5 . The adjusted $R^{2}$ of three proposed models are 0.31 , 0.23 and 0.39. All are fair and acceptable to concluding good models. All of five hypotheses are supported with statistical evidences.

Table3. Regression Analysis Results

\begin{tabular}{|l|l|l|l|}
\hline & \multicolumn{1}{|c|}{ Model 1 (EL) } & \multicolumn{1}{|c|}{ Model 2 (CS) } & \multicolumn{1}{|c|}{ Model 3 (CL) } \\
\hline Independent variables & & & \\
\hline Employee satisfaction & $0.35^{* *}$ & $0.19^{*}$ & 0.08 \\
\hline Employee loyalty & & $0.28^{*}$ & 0.11 \\
\hline Customer satisfaction & & & $0.41^{* *}$ \\
\hline Adjusted $R^{2}$ & 0.31 & 0.23 & 0.39 \\
\hline${ }^{*}<<0.05^{* *}{ }^{*}<0.01$ &
\end{tabular}

4. Conclusion

This study examined the effect of employee loyalty on customer satisfaction and loyalty based on service profit chain. While hiring part-time employees as the main sources of first line service providers may save labor costs, it is harder for hotels to maintain or improve service quality of these part-time employees because of the high turnover rate. According to the result of this research, it is best for hotel managers to hire formal employees with full pay grade, and improving work conditions of employees. Although the suggested approach will add to the labor costs, the improved employee satisfaction and loyalty will help employees' retention and service quality, and then improves customer satisfaction and loyalty. This enables a virtuous circle and allows companies to grow competitiveness i.e. experienced and loyal employees. The main contribution of this study is pointing out the contradiction between current hotel practices in Taiwan and empirical evidence. Cost down strategy does not have a positive influence on employee loyalty and thus cannot establish the path of service profit chain. Hotel managers should reevaluate their human resource strategy on how to retain the best employees instead of treating them as expandable and replaceable tools. In terms of future studies, researchers can attempt to find the causes of employee loyalty and to improve these criteria to achieving better customer responses. This study is constrained to a smaller sample size and singular geographic region. Future studies can consider expanding the span of the research to obtain a more generalized result. 


\section{REFERENCES}

Li, J. J., Kim, W. G., \& Zhao, X. R. (2017). Multilevel model of management support and casino employee turnover intention. Tourism Management, 59, 193-204.

Barsky, J. D., \& Labagh, R. (1992). A strategy for customer satisfaction. Cornell Hotel and Restaurant Administration Quarterly, 33(5), 32-40. doi:10.1177/001088049203300524

Bitner, M. J. (1990). Evaluating service encounters: The effects of physical surroundings and employee responses. Journal of Marketing, 54(2), 69-82.

Brown, E. A., Bosselman, R. H., \& Thomas, N. J. (2016). Are hospitality graduates making too many compromises? What they give up may lead to turnover. Journal of Human Resources in Hospitality \& Tourism, 15(2), 133-146.

Costen, W. M., \& Salazar, J. (2011). The impact of training and development on employee job satisfaction, loyalty, and intent to stay in the lodging industry. Journal of Human Resources in Hospitality \& Tourism, 10(3), 273-284. doi: 10.1080/15332845.2011.555734

Cronin Jr, J. J., Brady, M. K., \& Hult, G. T. M. (2000). Assessing the effects of quality, value, and customer satisfaction on consumer behavioral intentions in service environments. Journal of Retailing, 76(2), 193-218. doi: http://dx.doi.org/10.1016/S0022-4359(00)00028-2

Davidson, M. C. G., Timo, N., \& Wang, Y. (2010). How much does labour turnover cost?: A case study of australian four- and five-star hotels. International Journal of Contemporary Hospitality Management, 22(4), 451-466. doi: 10.1108/09596111011042686

Dick, A. S., \& Basu, K. (1994). Customer loyalty: Toward an integrated conceptual framework. Journal of the Academy of Marketing Science, 22(2), 99-113. doi: 10.1177/0092070394222001

Fornell, C., Johnson, M. D., Anderson, E. W., Cha, J., \& Bryant, B. E. (1996). The american customer satisfaction index: Nature, purpose, and findings. Journal of Marketing, 60(4), 7-18.

Gelade, G. A., \& Young, S. (2005). Test of a service profit chain model in the retail banking sector. Journal of Occupational and Organizational Psychology, 78(1), 1-22. doi:10.1348/096317904X2 2926

Heskett, J. L., Sasser, W.E., \& Schlesinger, L. A.(1997).The service profit chain: How leading companies link profit and growth to loyalty, satisfaction, and value. New York: Free Press.

Hinkin, T. R., \& Tracey, J. B. (2000). The cost of turnover: Putting a price on the learning curve. Cornell Hotel and Restaurant Administration Quarterly, 41(3), 14-21.doi:10.1177/0010880400 04100313

Homburg, C., Wieseke, J., \& Hoyer, W. D. (2009). Social identity and the service-profit chain. Journal of Marketing, 73(2), 38-54. doi: 10.1509/jmkg.73.2.38

Hunt, H. K. (1977). Conceptualization and measurement of consumer satisfaction and dissatisfaction. Cambridge, MA: Marketing Science Institute.

Ironson, G. H., Smith, P. C., Brannick, M. T., Gibson, W. M., \& Paul, K. B. (1989). Construction of a job in general scale: A comparison of global, composite, and specific measures. Journal of Applied Psychology, 74(2), 193-200. doi: 10.1037/0021-9010.74.2.193

Kamakura, W. A., Mittal, V., de Rosa, F., \& Mazzon, J. A. (2002). Assessing the service-profit chain. Marketing Science, 21(3), 294-317. doi: 10.1287/mksc.21.3.294.140

Karatepe, O. M., Karatepe, O. M., Kaviti, R., \& Kaviti, R. (2016). Test of a mediational model of organization mission fulfillment: evidence from the hotel industry. International Journal of Contemporary Hospitality Management, 28(5), 988-1008.

Kassinis, G.I.,\& Soteriou, A. C. (2003). Greening the service profit chain: The impact of environmental management practices. Production and Operations Management, 12(3), 386-403. doi: 10.1111/j.1937-5956.2003.tb00210.x

Kinicki, A. J., McKee-Ryan, F. M., Schriesheim, C. A., \& Carson, K. P. (2002). Assessing the construct validity of the job descriptive index: A review and meta-analysis. Journal of Applied Psychology, 87(1), 14-32. doi: 10.1037/0021-9010.87.1.14

Locke, E. A. (1969). What is job satisfaction? Organizational Behavior and Human Performance, 4(4), 309-336. doi: http://dx.doi.org/10.1016/0030-5073(69)90013-0

Loveman, G. W. (1998). Employee satisfaction, customer loyalty, and financial performance: An empirical examination of the service profit chain in retail banking. Journal of Service Research, 1(1), 18-31. doi: 10.1177/109467059800100103 
Matzler, K., \& Renzl, B. (2006). The relationship between interpersonal trust, employee satisfaction, and employee loyalty. Total Quality Management \& Business Excellence, 17(10), 1261-1271. doi: 10.1080/14783360600753653.

McCarthy, D. G. (1997). The loyalty link : How loyal employees create loyal customers. New York: Wiley.

McGinley, S. P., Hanks, L., \& Line, N. D. (2017). Constraints to attracting new hotel workers: A study on industrial recruitment. International Journal of Hospitality Management, 60, 114-122

Roznowski, M. (1989). Examination of the measurement properties of the job descriptive index with experimental items. Journal of Applied Psychology, 74(5), 805-814.doi:10.1037/00219010.74. 5.805

Silvestro, R., \& Cross, S. (2000). Applying the service profit chain in a retail environment: Challenging the "satisfaction mirror". International Journal of Service Industry Management, 11(3), 244-268. doi: 10.1108/09564230010340760

Smith, P. C., Kendall, L. M., \& Hulin, C. L. (1969). The measurement of satisfaction in work and retirement; a strategy for the study of attitudes. Chicago, Ill.,: Rand McNally.

Stanton, J. M., Bachiochi, P. D., Robie, C., Perez, L. M., \& Smith, P. C. (2002). Revising the jdi work satisfaction subscale: Insights into stress and control. Educational and Psychological Measurement, 62(5), 877-895. doi: 10.1177/001316402236883

Tongchaiprasit, P.,\& Ariyabuddhiphongs, V. (2016). Creativity and turnover intention among hotel chefs:The mediating effects of job satisfaction and job stress. International Journal of Hospitality Management, 55, 33-40.

Zeithaml, V. A., Berry, L. L., \& Parasuraman, A.(1996). The behavioral consequences of service quality. Journal of Marketing, 60(2), 31-46.

\section{AUTHORS' BIOGRAPHY}

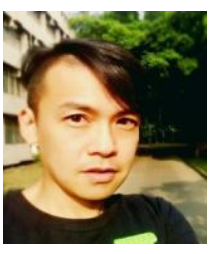

Dr. Yen-Cheng Chen, Assistant Professor, Department of Applied Science of Living, Chinese Culture University, Taipei, Taiwan. Current research interests include esthetics and atmosphere design in hospitality, Personnel education and training in food and beverage industry, and interpersonal relationship.

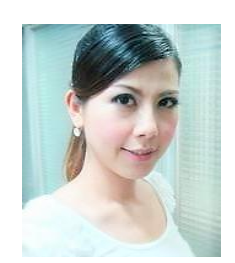

Pei-Ling Tsui, Assistant Professor, Department of Hospitality Management, National Taitung College, Taiwan, Doctoral Candidate of Department of Technological and Vocational Education in National Taipei University of Technology University. Current research interests include education in hospitality, organizational management and human resource management in hospitality.

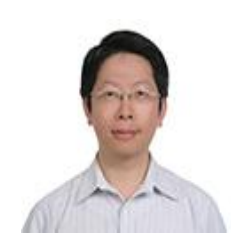

Ching-Sung Lee, Professor, Department of Restaurant, Hotel and Institutional Management, Fu Jen Catholic University, Taipei, Taiwan. Current research interests include Tourism and Hospitality Management. 